\title{
3 COVID-19, India, small- scale farmers, and indigenous Adivasi communities - the answer to the future lies in going back to the basics
}

\author{
Regina Hansda
}

\section{Introduction}

India has experienced one of the worst devastations to life and livelihoods from COVID-19. Part of the disaster and devastation has been humanmade. Lack of planning and preparation by the central government for tackling the COVID-19 pandemic dealt a massive blow to India's economy and caused enormous hardships to the poor and the vulnerable. The informal rural economy and the agriculture sector have been hardest hit (Singh, 2020). Central government's refusal to acknowledge the scale of the crisis and their mismanagement handling the medical emergency-turned-humanitarian crisis aggravates people's suffering and has deepened the crisis further. Both the first national lockdown announced in the last week of March 2020 with four hours of notice and the second wave of the pandemic have left devastation and grief of unimagined proportions. Two very grim and distressing images on national television and social media captured the imagination of the country and form a part of the collective failure and helplessness: first, the image of returning migrants with their young and old from the cities to the villages, walking thousands of miles for days with their minimal belongings; and, second, the image of the gasping COVID19 patients, lack of hospital beds and oxygen, and family members and relatives grieving the loss of their loved ones. Minimal reporting from the rural areas suggests that the situation is likely worse, considering the health infrastructure in the rural areas in ordinary times is inadequate. Both situations, spread over a year, show how the state abdicated its responsibilities for food security and public health, leaving individuals to fend for themselves.

This chapter focuses on the implications of food and livelihood insecurity on the poor and vulnerable sections of society. I demonstrate how 
government and its various institutions not only abdicated their responsibilities toward their citizens; instead, the pandemic was used as an opportunity to further dispossess and erode farmers', especially poor, Dalit, and Adivasi (indigenous peoples's), rights and resources. I argue that food and health is linked, and future farming and livelihoods for small-scale farmers and indigenous communities lies in going back to basics. By basics, I mean resisting, maintaining, and claiming what belongs to the community (knowledge systems, resources, and practices) so that power remains in the hands of the people and communities.

\section{COVID-19 lockdown, migrant crisis, food and livelihood insecurity issues}

The first COVID-19 lockdown triggered a large-scale trend of reverse migration across the country. As per the World Bank study (Ratha et al., 2020), roughly 40 million internal migrants (inter and intrastate) were affected by the lockdown. The countryside, for a change, became the site of hope for many. The main reasons for return migration on such a scale were the loss of livelihoods in the cities, inadequate savings to tide people over this crisis period, and staring at an uncertain future. Most of these homeward-bound migrants walking hundreds of miles on foot had one common refrain: "we don't know whether we will die of coronavirus, but we will certainly die of hunger." The food insecurity issues were massive and to some extent addressed by various citizens' groups and extra government rations (e.g., 5 $\mathrm{kg}$ of rice per household); but the experiences have been varied and inadequate in most areas.

The worst part of the countrywide lockdown, which kept extending in phases, was that it coincided with the country's peak harvesting season for a variety of crops (winter crops, wheat and barley - March-April; summer crops, vegetables and fruits - March-June). With the country coming to a sudden halt and disruption to supply chains, not only did all the hard work of farmers go to waste, but the pattern of labor-flow for the peak paddy season in the monsoons (rice/paddy; June-July) was disrupted (Figures 3.1 and 3.2). Agriculturally prosperous states like Punjab, Haryana, and Maharashtra witnessed labor shortages, while states like Bihar, Jharkhand, and Madhya Pradesh experienced a surge in the labor pool, which posed additional challenges to employment opportunities locally. The pandemic disrupted remittances, which migrants regularly sent to their households, affecting access to the everyday needs around food, nutrition, and health care of those who were in their home villages. 


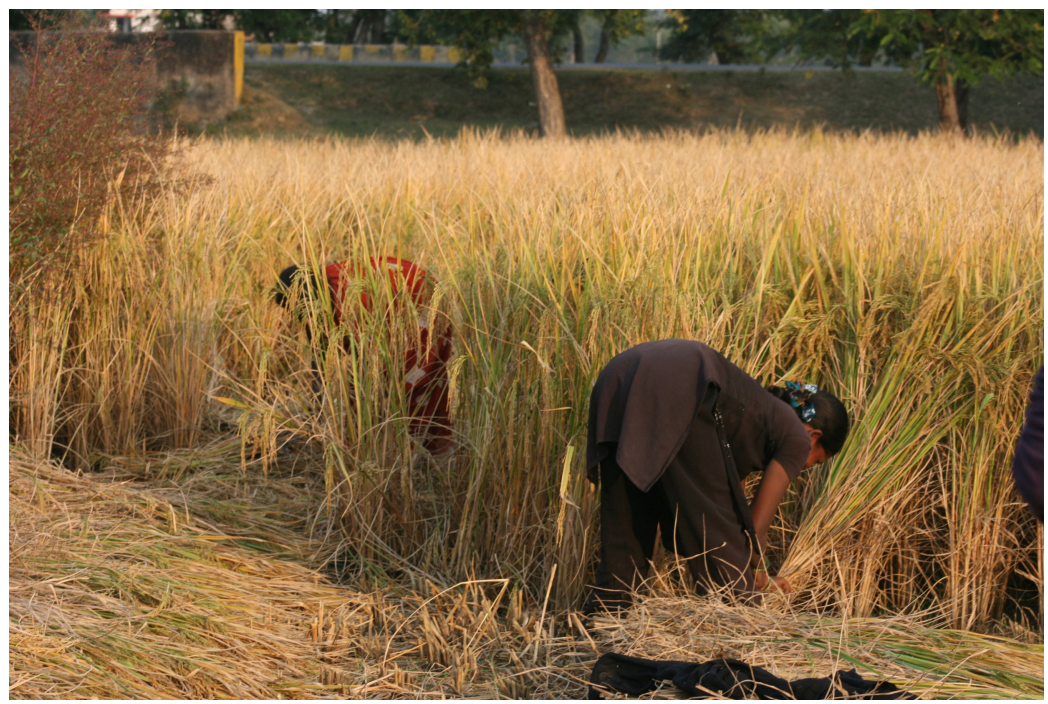

Figure 3.1 Paddy harvesting, Bihar (Regina Hansda).

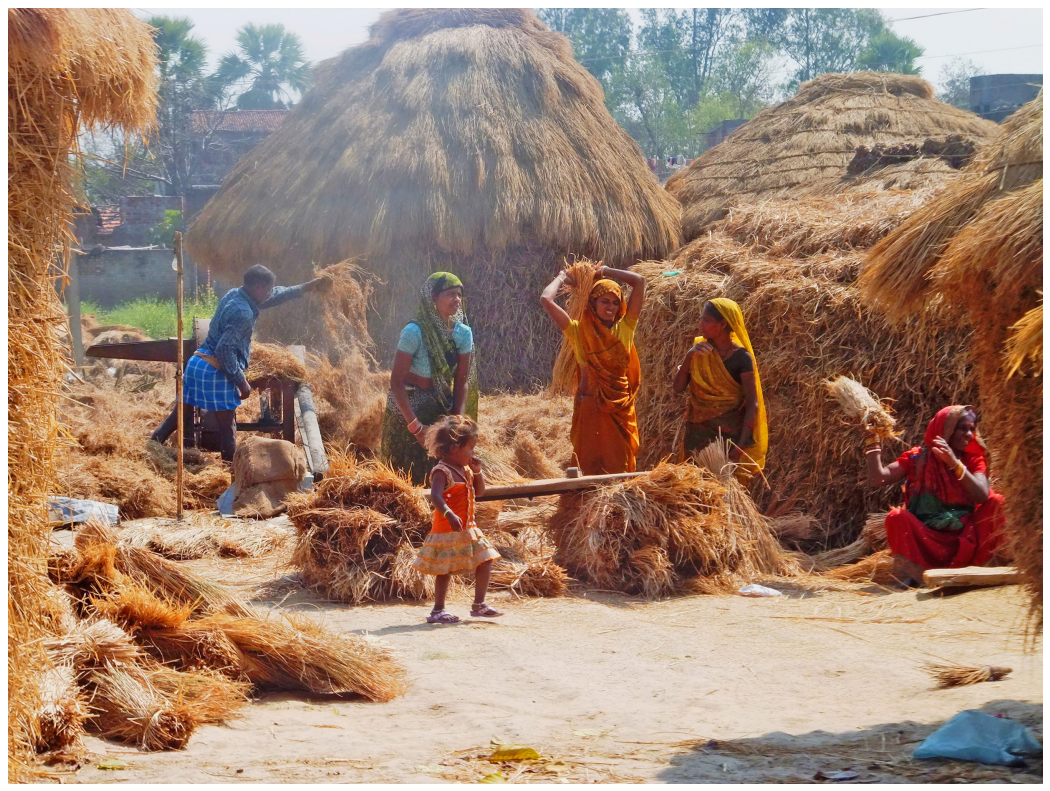

Figure 3.2 Paddy threshing, Bihar (Regina Hansda). 


\section{Impact of COVID-19 on rural women and inadequacy of government measures}

A study conducted by the Mahila Kisan Adhikaar Manch (MAKAAM) Forum for Women Farmers' Rights - across caste groups in the 17 districts of Maharashtra on the impact of COVID-19 and the lockdown on single women farmers and wage laborers found that overall food consumption declined in this period. "About 45 percent of women did not get a single day of work in the 50 days of the lockdown." Those with ration cards, apart from receiving their quota of rice and wheat at subsidised price, received additional food grains, but for a limited period of time (MAKAAM, 2020). SEWA-Bharat (2020) interviewed 300 women members in April-May in 12 states across 20 trades and found that only 5 percent were earning anything after lockdown. The government of India announced several relief measures for the returning migrants and farmers. However, because of inadequate gender considerations in planning and/or corruption issues, women farm workers stood the least chance to benefit from these measures. For instance, under the Pradhan Mantri Kisan Samman Nidhi (PM-KISAN) scheme with an allocated budget of Rs 1.7 lac crore (US\$25 billion), a small portion of that amount, Rs. 6,000 (US\$80.5), is meant to be provided to the small and marginal farmers as financial assistance during the lockdown (Varshney et al., 2021). However, the eligibility criteria for this scheme is land ownership and deed (patta) papers in the name of the applicant. In a country where 76 percent of women engaged in agriculture sector own about 13 percent of the agricultural land, this scheme excludes more than 87 percent of small and marginal women farmers, many of whom are landless. ${ }^{1}$ A small enquiry from a field site in Bihar, where I attempted to match the online government data ${ }^{2}$ with on-the-ground experiences of women farmers revealed gross corruption and mismanagement. For instance, the name of a beneficiary who I personally know from my ethnographic fieldwork was reflected thrice in the government website. Once, ascribing her gender as "male,' second as "female," and, on the third occasion, the gender was missing. There were many such repeated, misspelt names, and missing genders. This beneficiary list is a sad retelling of the jugglery that goes on in data manipulation and statistics to misappropriate government funds. Not only are such funds not utilized fully and properly, but the needs of the women farmers and agricultural laborers remain unattended.

In addition, the domestic became the site of healing, recovery, and care with an additional work burden on women in the rural areas. The domestic also became the site of increased domestic violence, which many saw as an additional health risk for women (Ghoshal, 2020). A few field contacts in telephone interviews indicated how agricultural laborers, who are mostly 
women, worked at almost half the wage rate during the paddy transplantation and harvesting season. For instance, the usual pattern of wage payment for agricultural labor work in Gaya district, my research site, is by both cash and kind, with kind payment often acting as the preferred mode of payment. The going rate for kind payment is $5 \mathrm{~kg}$ of rice (during transplantation), and one bundle on every 11 bundles of harvested paddy (gyarah gaahi mein ek gaahi) for the landholding farmer. The pandemic saw a breakdown of the village moral economy. The monsoons were good, they came on time, and despite the relative surplus production from the previous year, the agricultural workers were paid less. The few generous landholding farmers who occasionally would pay extra wages or share produce from their kitchen gardens (e.g., banana, or chicken to be shared by the laborers after harvest) preferred not to, as a cautionary measure. This cautious approach meant additional food security implications for the wage workers who are mostly from Dalit communities. In addition, the employment under Mahatma Gandhi National Rural Employment Guarantee Act (MNREGA), which guarantees 100 days of rural employment to interested wage workers from each household, witnessed an increasing surge in demand because of the returnee migrants and the State's inability to keep pace with the demand. With the increase in unpaid work, and the absence of support from male family members, women's mental and physical exhaustion have been aggravated by the lack of food, income, and an uncertain future. Single women households, with a limited social network and no savings, have been the worst affected (Dutta, Agarwal and Sivakami, 2020).

\section{Impact on indigenous Adivasi women}

A significant population of Adivasis are dependent on forest-based livelihoods and were impacted heavily by the lockdown. The non-wood forest products (NWFPs) that are utilized and commercialized are seasonal in nature, with more than half of their annual income accruing during the months of March to June, which is also the lean period for them. This year it coincided with the lockdown period. Some of the harvested NWFPs (mostly leaves, tubers, green leafy vegetables, fruits, and berries) include tendu leaves (Diospyros melanoxylon), wild honey, tamarind, mango, sal leaves, sal seeds, mahua flowers, mahua seeds, and achaar seeds amongst others. Many of these NWFPs are food items consumed for household food and nutrition security needs, with the surplus sold in the local markets or to the government procurement agencies. The cash earned during these months is critical for sustenance during the monsoon season when 
employment dries up. However, because of the lockdown restrictions, both the government procurement agencies as well as the local traders delayed their procurement, or procured far less than usual, or at a distresssale rate, thereby risking the livelihoods of millions of forest-dependent communities.

\section{The pandemic as an opportunity to erode farmers and Adivasi people's rights}

The government's lockdown mantra has been "Aapda mein avsar" (opportunity in crisis) and such a philosophy and outlook has resulted in initiatives and outcomes that have adversely affected the farming sector and the Adivasi people. For instance, the pandemic saw the institution of the three New Farm Laws without much debate and discussion in parliament. Also, large-scale clearances to environmental projects have adversely impacted the Adivasi people.

\section{The three Farm Laws ${ }^{3}$ and farmers' resistance}

The government claims that the three newly constituted Farm Laws are designed to modernize the farming sector and to double farmers' incomes. The farmer protests where women farmers have played a proactive and leading role suggest otherwise. After more than six months of protests, the battle between the government and the farmers on the Farm Laws is on, on the outskirts of Delhi, and it appears likely to continue until a reasonable resolution. The farmers who resist are from states which have been the sites of the Green Revolution (Punjab, Haryana, and Western Uttar Pradesh). These farmers have experienced the "modern methods" of farming and its associated increased farm productivity and profitability. But along with increased prosperity, they have also witnessed the destruction of the ecological basis for farming (e.g., declining soil fertility, depleting water table) (Sidhu and Dhillon, 1997). The farmers in these areas are aware of the inappropriateness of the mono-cropping systems that they have been practicing, the artificiality of subsidies on agro-chemicals, and how it is only the guaranteed minimum support price and the Mandi system that has kept such a system of farming alive. So why are these farmers protesting in a do-or-die kind of battle? Why is there an outpouring of national and international solidarity to their cause? ${ }^{4}$ It is the belief that these Farm Laws are formulated to streamline greater capital accumulation by corporations without safeguards for the farmers; it is the fear of indebtedness and the fear of losing the freedom to practice farming on their own terms (Bhattacharya 
and Patel, 2021). Moreover, the New Farm Laws, by the very nature of their ambiguity and lack of social protection, foreclose the possibilities of farmers returning to sustainable methods of farming. What lessons can be drawn from these farmers' protest for the farming sector in general, and especially for resource-starved small-scale farmers? In simple words, they must hold on to their land and farming systems until and unless a clear blueprint and pathway for their transition and progression to alternative sources of livelihoods are planned by policymakers.

\section{Indigenous communities, COVID-19, and continued state repression}

Under cover of the pandemic both overt and covert land grabs have been ongoing in the tribal hinterlands in the name of development works such as plantations (Sushmita, 2020, 2021), mining (Agarwal, 2020), and hydroelectric projects (Pinto and Van Adhikar Media Team, 2020). Attempts to resist the slow encroachment of Adivasi land has met with brutal police assaults and death. For instance, in a recent face-off in Bastar forests against road construction where three people died, one of the witnesses, Krishna Kadti, 18, a Class 12 student from Jagargunda shares:

we were beaten up by the security forces when we went to submit our demands. They beat us earlier too. We also got angry and some of our people pelted stones at their vehicles and at the camp. First, the security personnel threw tear gas bombs, and then opened fire.

(Verma, 2021)

Similarly, on the issue of livelihoods, Rajanti Malik from Kandhamahal district, Odisha, shares the ordeal of her community:

In the midst of this lockdown, while we were told to stay at home, the forest department destroyed and cleared our natural forests. They came and cleared the existing forest, on which we depend for food and livelihood, to plant other trees (afforestation under CAMPA) ... Due to the coronavirus lockdown, we couldn't even sell our Siali leaf and Sal leaf plates, Tendu or Bahada and all of these are getting spoiled. We are feeling helpless and are unable to understand how to feed and safeguard our children. In this crisis, between lockdown restrictions and the Forest Department actions, we are helpless. How will we survive?

(Pinto and Dubey, 2020) 
For most of these projects, the government gave speedy environmental clearances without any field visits or due process such as stakeholder consultations, environmental and social impact assessments and based their decisions only on reports submitted by the project proponents. In addition, they arrested leading Adivasi environmental activists (e.g., Hidme Markam), who have been keeping a constant community vigil on state and corporate aggression of their land and forests, on concocted charges during the pandemic.

\section{Going back to the basics to strengthen rural communities and women farmers}

COVID-19 should be seen as a wake-up call for humanity, to reflect on and rethink the rural. The pandemic in general reminds us any disruptions and shocks disproportionately affect the already disadvantaged. It has also shaken the uncontested idea that the future lies in the urban, and in the cities and that work and leisure cannot be organized in a more carbon-efficient way. The pandemic provides us with the opportunity to rethink, reclaim, and redesign food systems that can ensure safe, healthy, sustainable, and resilient communities that recognize and build on local knowledge systems and practices. However, without addressing the central questions around land and tenurial security of the peasantry, any progress is likely to be peripheral and temporary.

\section{Addressing landlessness, food insecurity through land reforms, and access to forest rights}

Landlessness is a massive issue in India. According to the 2011 SocioEconomic and Caste Census, 56 percent of households in rural India do not own any agricultural land. Landless farmers are disproportionately women, and belong to the Dalit and Adivasi communities. These two categories and mostly women from Dalit and Adivasi communities comprise the bulk of the laboring class in agriculture and allied activities. Many of the relief and recovery measures promoted by the government automatically exclude most women smallholders, tenant farmers, sharecroppers, and daily agricultural wage laborers. The only way to redress this inequity and reduce the marginalization of the poor and the vulnerable is through seeking creative ways of land redistribution. In the case of Adivasis, it is important that the inalienable forest rights of the Adivasi communities are upheld and maintained by all concerned. The Adivasis must resist all attempts at state appropriation of their lands and territories. In addition, the wider public must question respective governments and make them accountable for all the state-mediated violence in the Adivasi and tribal areas, including all 
attempts by governments to dilute environmental laws which create an easy pathway for corporate land grabs.

\section{Encouraging agro-ecological farming for long-term sustainability and resilience}

Food insecurity has been one of the main concerns of this pandemic and it has been articulated by multiple food activists and agencies like FAO, IFAD, and La Via Campesina, among others. With the closing of borders and disruption of supply chains, one of the main lessons of the pandemic is the importance of locally produced food, especially vegetables and fruit. There is increasing recognition that by boosting investment for agroecology in the rural areas we can feed the world and strengthen our resilience against this crisis, and those yet to come. As food supply chains break down, community supported agriculture (CSA) shows us the way. For instance, the North East Slow Food \& Agrobiodiversity Society (NESFAS), Meghalaya, through their weekly market in the last couple of years serves as an effective platform for producers and consumers to come together and buy and sell organically produced indigenous food crops, including, different varieties of wild edibles. The COVID19 lockdown disrupted this platform. However, some women farmers, who are also part of the participatory guarantee scheme were able to improvise and create an alternative supply chain through the "Farm on wheels" initiative, enabling access to their produce by willing consumers. There are many such small, local, individual, as well as community, initiatives that require incentivization and support. Studies point to more women-centric group approaches as new pathways for a post-COVID-19 future (Agarwal, 2021).

\section{Going beyond rhetoric to reality}

One of the clarion calls given during the pandemic by the Indian prime minister was the idea of Atmanirbharta - which means striving toward self-sufficiency. Contrary to what the three New Farm Laws claim, one of the ways of addressing the impending challenge of food insecurity and the protracted conditions of agrarian crisis in the country is to recognize the value of diverse, small-scale, sustainable food production systems across diverse agro-climatic zones instead of paving the way for corporate agriculture. The skill sets and knowledge of farming rests with the rural farming community, many of whom are marginal and small farmers, and it is incumbent upon governments to recognize the need for supporting food production systems that cater to their needs and interests. In addition, it is critical that the central questions around land access and tenurial security of farmers, across various intersections (gender, caste, class, ethnicity, religion, marital status) are addressed. Robust investments are needed for research and development that support and 
encourage small-scale farming. Policies are needed that protect and enhance marginal Adivasi and Dalit women's access to forests and other communal resources (water, grazing land) without dispossessing and eroding their rights.

\section{Conclusion}

In the past year since the COVID-19 lockdown it has become abundantly clear that the state abdicated its responsibility toward its citizens as far as food/livelihood security and public health is concerned. The resistance to the three New Farm Laws, with proactive participation and leadership by women farmers across caste and class, is an indication of the breakdown of trust between farmers and the government. Similarly, the Adivasis, with proactive leadership from women across the central Indian states over decades, have been resisting the imposition of the dominant development paradigm that undermines their foodways and ways of life, which are based on sustainable harvesting practices. It is pertinent to remind ourselves that a fair and just future is only possible when those most vulnerable have meaningful participation and a say in the transition process of the new imagined nation.

\section{Notes}

1 Landesa report: Land matters: Success stories of women land owners in India.

2 https://pmkisan.gov.in/Rpt_BeneficiaryStatus_pub.aspx

3 The New Farm Laws deal with production, storage, and marketing of farm produce.

4 Tweets by Rihanna and Greta Thunberg and other activists, academics, and policymakers.

\section{References}

Agarwal, B., 2021. Livelihoods in COVID times: Gendered perils and new pathways in India. World Development, 139, p.105312.

Agarwal, M. 2020. India's mining sector: Present is tense and future could be imperfect. https://india.mongabay.com/2020/07/indias-mining-sector-present-is -tense-and-future-could-be-imperfect/ Accessed on 4 May, 2021.

Bhattacharya, S. and Patel, U., 2021. Farmers' agitation in India due to audacious Farm Bill of 2020. International Journal of Research in Engineering, Science and Management, 4(1), pp. 35-37.

Chopra, D., 2014. 'They Don't Want to Work' versus 'They Don't Want to Provide Work': Seeking explanations for the decline of MGNREGA in Rajasthan.

Dutta, M., Agarwal, D. and Sivakami, M., 2020. The "invisible" among the marginalised: Do gender and intersectionality matter in the Covid-19 response?. Indian Journal of Medical Ethics, 5(4), pp. 302-308. 


\section{Regina Hansda}

Ghoshal, R., 2020. Twin public health emergencies: Covid-19 and domestic violence. Indian Journal of Medical Ethics, 5, pp. 1-5.

Kumar, S. and Choudhury, S., 2021. Migrant workers and human rights: A critical study on India's COVID-19 lockdown policy. Social Sciences \& Humanities Open, 3(1), p. 100130.

Landesa report (undated). Land matters: Success stories of women land owners in India.

MAKAAM, 2020. Unlocking the Crisis: Understanding impacts of COVID -19 and subsequent lockdown on single women farmers of Maharashtra. June 2020.

Pinto, A. and Dubey, S., June 2020. Adivasi and forest dwelling women across India face the brunt of the Covid Pandemic: Voices from the Ground Part-1. https:// www.behanbox.com/adivasi-and-forest-dwelling-women-across-india-face-the -brunt-of-the-covid-pandemic-voices-from-the-ground/ Accessed on $31 \mathrm{March}$, 2021.

Pinto and Van Adhikar Media Team, 2020. "How the Government Diluted Forest Rights of Adivasis During Lockdown." Behar Box, July 19, 2020.

Ratha, D. K., De, S., Kim, E. J., Plaza, S., Seshan, G. K. and Yameogo, N. D., 2020. COVID 19 crisis through a migration lens (No. 147828, pp. 1-50). The World Bank, April.

SEWA-Bharat, 2020. Gendered precarity in the lockdown. http://www.sewabha ratresearch.org/wp-content/uploads/2020/05/Gendered_Precarity_SB_Lock down-1.pdf

Sidhu, R. S. and Dhillon, M. S., 1997. Land and water resources in Punjab: Their degradation and technologies for sustainable use. Indian Journal of Agricultural Economics, 52(3), pp. 508-518.

Sushmita, 2020. Pandemic unleashes fresh hell for India's adivasis. The Third Pole. https://www.thethirdpole.net/en/livelihoods/pandemic-unleashes-fresh-hell-for -indias-adivasis/ Accessed on 4 April, 2021.

Sushmita, 2021. Plantations over people: India's Covid-19 recovery plan for indigenous groups. https://www.thethirdpole.net/en/livelihoods/plantations-over -people-indias-covid-19-recovery-plan-for-indigenous-groups/ Accessed on 18 May, 2021.

Singh, B. P., 2020. Impact of COVID-19 on rural economy in India. MPRA Paper 100530, University Library of Munich, Germany.

Varshney, D., Kumar, A., Mishra, A. K., Rashid, S. and Joshi, P. K., 2021. India's COVID-19 social assistance package and its impact on the agriculture sector. Agricultural Systems, 189, p. 103049.

Verma, G. 2021. Chhattisgarh: Three dead in firing on protest, villagers dig heels in at Sukma security camp. MSN News. https:/www.msn.com/en-in/news/other /chhattisgarh-three-dead-in-firing-on-protest-villagers-dig-heels-in-at-sukma -security-camp/ar-BB1gSMaU Accessed on 20 May, 2021.

Zaidi, M., Chigateri, S., Chopra, D. and Roelen, K., 2017. "My Work Never Ends": Women's experiences of balancing unpaid care work and paid work through WEE programming in India. IDS Working Paper 494, Brighton: IDS. 